\title{
Empirical Test of Single Factor and Multi-Factor Asset Pricing Models: Evidence from Non Financial Firms on the Ghana Stock Exchange (GSE)
}

\author{
Prince Acheampong ${ }^{1} \&$ Sydney Kwesi Swanzy ${ }^{2}$ \\ ${ }^{1}$ Department of Accountancy, Koforidua Polytechnic, P.O. Box KF981, Koforidua, Ghana \\ 2. School of Business, Kwame Nkrumah University of Science and Technology (KNUST), Kumasi, Ghana \\ Correspondence: Prince Acheampong, Department of Accountancy, Koforidua Polytechnic, P.O. Box KF 981, \\ Koforidua, Ghana. Tel: 233-248-623-124. E-mail: owoahene6@yahoo.com
}

Received: October 12, 2015

Accepted: November 12, $2015 \quad$ Online Published: December 25, 2015

doi:10.5539/ijef.v8n1p99

URL: http://dx.doi.org/10.5539/ijef.v8n1p99

\begin{abstract}
This paper examines the explanatory power of a uni-factor asset pricing model (CAPM) against a multi-factor model (The Fama-French three factor model) in explaining excess portfolio returns on non-financial firms on the Ghana Stock Exchange (GSE). Data covering the period January 2002 to December 2011 were used. A six Size- Book-to-Market (BTM) ratio portfolios were formed and used for the analysis. The paper revealed that, a uni-factor model like the (CAPM) could not predict satisfactorily, the excess portfolio returns on the Ghana Stock Exchange. By using the multi-factor asset pricing model, that is, the Fama-French Three Factor Model, excess portfolio returns were better explained. It is then conclusive enough that, the multi-factor asset pricing model introduced by Fama and French (1992) was a better asset pricing model to explain excess portfolio returns on the Ghana Stock Exchange than the Capital Assets Pricing Model (CAPM) and that there exist the firm size and BTM effects on the Ghanaian Stock market.
\end{abstract}

Keywords: portfolio returns, stock market, Book-to Market (BTM) ratio, Beta

\section{Introduction}

Sharpe (1964), Lintner (1965), and Black (1972) (SLB) provided finance professionals and academics a means of showing the relationship between the average returns on a portfolio or investments and the risk associated with it through their asset pricing models. This occasioned the asset pricing model known as the Capital Asset Pricing Model which is referred to as the CAPM. This model has been a central piece of modern financial economics and proceeded in the awarding of the 1990 Nobel Prize in Economics to William F. Sharpe, as one of the first proponent of the CAPM. CAPM is based on the central idea that the market portfolio of invested wealth is mean-variant efficient. Given this idea of mean-variance efficiency of the market, it is assumed that investors are rational and choose portfolios that: (1) minimize the variance of portfolio return, given expected return, and (2) maximize expected return, given variance. This suggests that: (1) the expected returns on a security is a positive linear function of the Market beta (the slope in the regression of a security's return on the market's return), and (2) Market beta is to describe the cross-section of expected returns (Fama \& French, 1992).

What makes the CAPM attractive is that, it offers a powerful and intuitive predictions about expected returns and risk, as well as risk management in general. Unfortunately, the empirical records of this model is poor. Despite early test by researchers including; Black, Jensen, and Scholes (1972), which supported the CAPM, the explanatory power of beta $(\beta)$, was criticized and showed not to be the only factor that adequately describes returns of securities.

Fama and French (2004) opines that, the empirical problems associated with the CAPM could be the result of theoretical failings, caused by over simplified assumptions. They further argue that the model's problems are as a result of weaknesses in its empirical implementations. This goes on to imply that, the failure of the CAPM in empirical tests indicated that most of the models applications were invalid. Thus, the onetime revered uni-factor model of asset pricing is seen as a not so reliable model to explain returns of securities. These contradictions and empirical test failures of the CAPM, provided researchers with reasons that expected returns on securities are not affected by just one factor, 'beta', but that other factors which also play a significant role in determining 
returns on securities. This resulted in a new way of looking at asset pricing and hence the multi-factor asset pricing model emerged as a more realistic model which is able to explain the returns of securities based on not just one factor but other important variables that affected securities' returns. (Bodie et al., 2010).

Ross (1976) introduced the Arbitrage Pricing Theory (APT) as an alternative to the CAPM. This new multi-factor model has the momentum to overcome some of the weaknesses of the CAPM. The APT in its sense requires less assumptions, which are more realistic with an explanatory power better than the single factor CAPM. The main difference in the APT and CAPM is that the multi-factor approach allows for an unspecified number of equally important factors to be included. The factors could include the CAPM's market beta, but it does not necessarily have to be one of them. The idea being that CAPM and APT are two independent theories. However the issue with using the APT model is that, firstly the multi-factor approach does not specify what the risk factors are, and which factors are to be used. Secondly it does not state the number of unknown risk factors. These limitations causes each user of the APT model to specify his/her own risk factors. The implication of this is that, an investor using this model is never sure of what relevant risks are being accounted for. There is therefore the need to have a model which is able to specify the type and number of risks to be used.

Fama and French (1996) proposed a three-factor model in the quest to describe the returns on securities. This model known as the Fama-French Three-Factor Model (FFTF) is also a multi-factor asset pricing model that relates the returns on the securities to three relevant risk factors. This model which was proposed to explain the failures of CAPM have been widely tested in other markets to ascertain its validity. The FFTF model explains returns on securities based on market beta, size, and book-to-market (BTM) ratio. This is widely explained and tested in the papers presented by Fama and French (1992) and also, Fama and French (1996). Despite the criticisms received by their findings, other researches have been done to disprove most of the critics. Others argue the findings were specific to US stock, and new data must be used to test the validity of the model in different economies. Interestingly, this Fama-French model has not been tested with data from Ghana. This paper therefore seeks to examine the explanatory power of the CAPM (A Uni-factor model) as against the Fama-French Three-Factor Model (FFTF) on the Ghana Stock Exchange and to find out whether earlier evidence by Fama and French (1992) are consistent with the Ghanaian Stock Market.

\section{Review of Empirical Literature}

We conduct a review of some the empirical findings related to this paper as below.

\subsection{A Uni-Factor Model: CAPM}

One of the earliest empirical studies of the CAPM was that of Black, Jensen, and Scholes (1972). Their results were found to be consistent with the predictions of the CAPM, given the fact that the CAPM was an approximation to reality just like any other model. Furthermore one of the classic empirical studies of the CAPM was by Fama and MacBeth (1973); they examined the possibility of a linear relationship between the calculated average returns and beta, and if any its nature. Applying data for stocks that were traded on the NYSE during the time period from 1926 to 1968, they looked at the explanatory power of squared value of beta and the volatility of returns on an asset, to see whether they could also explain residual variations in average returns which were not explained by the beta value alone. Their conclusion is that the data generally support the CAPM.

To enhance the efficiency and effectiveness of the beta estimates, researchers including, Black, Jensen and Scholes (1972) constructed portfolios, instead of using individual securities. Knowing well that expected returns and market betas combine in the same manner as do portfolios, it is suggested that if the model used explains individual stock returns then it can also explain returns of the portfolios. Contrarily, it has been shown by several research works that estimates of beta are more precise for diversified portfolios than individual securities in general.

CAPM's efficiency has been greatly criticized by several researchers. Reilly and Brown (2000) questioned the steadiness of beta and the linear relationship between assets return and its rate of return. Acheampong and Agalega (2013) tested the applicability of the standard CAPM on selected stocks from the financial sector of the GSE. They found out that the standard CAPM could not explain the excess returns on the selected stocks.

\subsection{Multifactor Model: Fama-French Three Factor Model}

Fama and French (1992) proposed a form of multi-factor model based on three factors and has become a standard tool for empirical studies of asset returns. They added two new independent variables, that is, firm size and the book-to-market (BTM) ratio to the market beta as additional explanatory factors for average returns. These new factors incorporated to the already existent market beta factor, were inspired by earlier observations that saw average returns of high BTM stocks and small firm stocks being historically higher than forecasted by the Security Market Line (SML) of the CAPM. This however, supported the idea that firm size and the BTM may be 
deputations for exposure to sources of systematic risk which eludes the beta of CAPM. Fama and French (1996) point out that firms with high BTM are more probable to be in financial distress and that small size firm stocks may be more sensitive to variations in business environments.

While the high book-to-market group includes many firms in financial distress which depresses market value relative to book value; for the most part, this group includes relatively mature firms. The latter derives a larger share of their market value from assets already in place, rather than growth opportunities. This group is often called "value-stocks". In contrast, low BTM companies are viewed as "growth firms" whose market values derive from anticipated future cash flows, rather than from assets already in place. Considerable evidence suggests that value stocks trade at lower prices than growth stocks (or equivalently, have offered a higher expected rate of return): the differential is termed as the value premium.

Fama and French (1996) argued that many of the CAPM average return anomalies were actually related and can be captured in its Three-Factor model. The model state that, the expected return on a portfolio in excess of risk-free rate $\left[E\left(R_{i}\right)-R_{f}\right]$ can be explained by the sensitivity of its return to three factors:

I. The excess return on a broad market portfolio $\left(R_{m}-R_{f}\right)$.

II. The difference between the returns on a portfolio of small stocks and the return of a portfolio of large stocks (SMB, Small minus Big).

III. The difference between the returns on a portfolio of high Book-to-Market (BTM) stocks and the return on a portfolio of low book-to-market (BTM) stocks (HML, high minus low).

The model as proposed by Fama and French specifically, the expected excess return on portfolio ' $i$ ' $i$ is

$$
E\left(R_{i}\right)-R_{f}=b_{i}\left[E\left(R_{m}\right)-R_{f}\right]+s_{i} E(S M B)+h_{i} E(H M L)
$$

$E\left(R_{i}\right)=$ expected returns on asset $i$

$E\left(R_{m}\right)=$ expected return on the market

$R_{f}=$ risk-free rate

$b_{i}=$ factor loading for excess return on market

$s_{i}=$ factor loading for size

$h_{i}=$ factor loading for $B T M$

\subsubsection{The Size Effect}

Regression results from Fama and Macbeth (1973) provided evidence that shows significant negative relation between stock returns and stock market value. However the effect of firm size was evidently not linear and most distinct for firms with the smallest size in the sample. Banz (1981) arguably provided may be the first of the many empirical papers which seemed to provide evidence of size effect on stocks returns in the US markets. His analysis was primarily on all common stocks which were listed in the time period between 1936 and 1975 on the NYSE. He re-counted that securities in the quintile portfolio with minimum market capitalization (size) were able to make a risk-adjusted return that was $0.4 \%$ per month higher than all other remaining firm stock's. Banz (1981) inferences that a number of investors were not interested in holding small firm stocks due to insufficient information relating to it, hence leading to its higher stock returns. Reinganum (1981) also analysed the effect of firm size on several firms, which included a sample of firm stocks on the NYSE and Amex, 566 in total; spanning over a period from 1963 to 1977. Reinganum (1981) showed that the smallest size decile portfolio outdoes those of the largest portfolio by $1.77 \%$ per month. Brown et al. (1983) re-examined the data used by Reinganum (1981) and found that there seemed to exist an approximate relation between the daily stock returns on the decile size-based portfolios and the logarithm of its average market capitalization. This relation however was deemed to be linear.

Whiles there seems to have been a wide number of important contributions being provided in the years after the original work by Banz (1981), investigations on the size effect became more of a concern after the emergence of Fama and French (1992). They looked at the effects of firm size and book-to-market anomalies revealed by earlier works and made the case that criticisms of the shortfalls of the Capital Asset Pricing Model (CAPM) of Sharpe (1964) and Lintner (1965) in the face of empirical evidence were imperative to be sidelined and ignored as mere anomalies. Employing data sample from the Amex, NASDAQ, and NYSE stocks across the period 1963 to 1990, they indicated that smallest decile size-based portfolio outperformed the largest by $0.63 \%$ per month. They also indicted that beta had no relation with returns upon subdividing each size decile into 10 beta -sorted portfolios. It was also revealed by Fama-Macbeth regressions that firm size and book-to-market equity had significant explanatory power in describing the cross-section of returns of stock and that beta was flat in explaining the 
cross-section of returns.

Despite the load of studies supporting the size effects on returns. Critiques argue that most of these studies are either statistical flukes or as a result of data selections, and method of forming the portfolio sizes. It was pointed out that investigators if they employ a market portfolio that contrast with the actual market portfolio, then the betas estimated are with error. Black (1993) made this observation afore mentioned. It is expected that stocks that seem to have low betas may on the average have a higher betas should their true market portfolio be used. This then turn to nullify the analysis of whether the higher stocks return on small firm stocks establishes premium for extra market risk. Pettengill et al. (1995) criticized the methodology used by Fama and French (1992). Their assertion was that the methodology didn't take into account the predictions of CAPM were grounded on expected returns and for that much imposition of restrictions that the beta-return relationship was the same in up-markets and down-markets. When these restrictions were relaxed, they found a significantly positive and negative betas in up-markets and down-markets respectively.

Berk (2000) also criticized the methodology of sorting the stocks into portfolios of size initially and then after testing the explanatory power of an Asset Pricing Model within each size decile as being bias. He elaborates that this technique is skewed toward the rejection of whatever Asset Pricing Model being examined in the second sorting step. The perception is that in the initial step, by selecting a factor that is empirically known to exhibit a relation to stock returns, the return variation across the group is high. Hence, the variation within groups is however small and the evidence statistically available not to accept the null of a flat beta-return relation is low. Pettengill et al. (2002) in their follow-up study argued that firm size association with cross-sectional return premium was also asymmetric, indicating firm size effect is more marked in down markets. They contend that common assumptions of having betas the same in both down and up markets tips to an underestimation of the firm size effect. Ferguson and Shockley (2003) established that if the market deputation used in empirical test of the CAPM was only equity, features correlated with a firm's relative distress and leverage will appear to explain stock returns.

\subsubsection{Book-to-Market (BTM) Ratio Effect}

Fama and French (1992) study findings encouraged the use of Book-to-Market (BTM) ratio. They provided evidence empirically that the BTM had the ability to explain variations in cross-sectional returns of individual stocks. Kothari and Shanken (1997) used a Bayesian framework to certify that the BTM of stocks on the Dow Jones Industrial Average (DJIA) Index was able to predict market returns over the period 1926 to 1991. They showed BTM could also forecast negative expected returns, however this assertion is weak and not robust towards the latter half of their sample. Empirical evidence and works documenting the explanatory power of the BTM over securities/stock returns are not scarce. Most recent studies on this variable include those in Hong Kong, Japan, Korea, Malaysia, Philippines, Italy, U.S. and the U.K. Akgun and Gibson (2001) postulates that BTM and size may include useful information concerning both the distress risk, as well as probability of bankruptcy and recovery rates. Vassalou and Xing (2004) hypothesize that effect of BTM is mainly as a result of default effect, however existing in parts of the market where there is high default risk.

Based on the above evidence some of which support the Fama and French three-factor model whiles others critiqued the model's estimations and applicability in assessing the returns of stocks on the developed markets; we extend the discussion to include a developing market; the Ghana Stock Exchange.

\section{Empirical Methodology}

The empirical procedures adopted for this paper are as discussed below.

\subsection{Sources and Type of Data}

The data for this paper includes end of month closing stock prices of non-financial firms listed on the Ghana Stock Exchange (GSE) from January 2002 to December 2011. The study period was selected because of the improvement of the workings of the exchange as well as increased number of companies listing on the exchange, during this time period. The data period also reflected the time when the market was seen to be growing and there was a good feeling about the Ghanaian capital market and saw a rise in the market capitalisation of the GSE. This comprises of both de-listed and listed firms during the study period. The data provides the values for all surviving firms during the period and only firms which were delisted during the period of study have missing values corresponding to the time after delisting. This data selection was done to dispel data snooping bias argument. This paper uses only non-financial firms, since financial firms normally have high leverage and the implication of high leverage to financial firms are different to non-financial firms. The accounting data used in computing the Book-to-Market (BTM) and size were obtained from the GSE facts books, as well reported 
annual financial statements of the firms involved. Thus, only secondary data were used in this paper.

\subsection{Empirical Model Specifications}

\subsubsection{The CAPM}

The CAPM is based on the assumption that beta is the main determinant of systematic risk to explain stock returns. The model is shown below:

$$
E\left(R_{i}\right)=R_{f}+\beta_{i}\left[E\left(R_{m}\right)-R_{f}\right]
$$

Where:

$E\left(R_{i}\right)=$ expected return on asset/portfolio $i$

$E\left(R_{m}\right)=$ expected return on the market

$R_{f}=$ return on risk free asset

$\beta_{i}=$ asset beta $=\frac{\operatorname{Cov}\left(R_{i}, R_{m}\right)}{\operatorname{Var} R_{m}}$

\subsubsection{The Fama-French Three Factor (FFTF) Model}

Following Fama and French (1993) three factor model, the multi-factor model adopted for this paper is specified as follows:

Where:

$$
E\left(R_{i}\right)-R_{f}=b_{i}\left[E\left(R_{m}\right)-R_{f}\right]+s_{i} E(S M B)+h_{i} E(H M L)
$$

$E\left(R_{i}\right)=$ expected returns on asset/portfolio $i$

$E\left(R_{m}\right)=$ expected return on market

$R_{f}=$ risk-free rate

$b_{i}=$ factor loading for excess return on market

$s_{i}=$ factor loading for size

$h_{i}=$ factor loading for BTM

\subsection{Size-BTM Portfolios Formation Process}

Since the GSE is a fairly small market a six (6) Size-BTM portfolios is formed. Firstly, stocks are sorted from the smallest to the biggest in terms of market capitalization or value. The stocks after being sorted from the smallest to the biggest were then divided into two groups by using the mid-point (median) of the market value of the sample stocks at the end of each year. Portfolios whose market value were lower than the median were designated as small size(S) and those whose market value were bigger than the median were assigned as big size (B).

The stocks after being sorted into two groups on the basis of size, were then sorted into three BTM portions independently by their BTM ratios again. This sorting into BTM portioning is done for each year of the study period. The partitions were designated as High $(\mathrm{H})$, Medium (M), and Low (L). The breakpoints or levels for the partitioning was the top $30 \%, 40 \%$ midsection, and bottom $30 \%$ of the BTM figures that were computed. The high BTM ratios portfolios contained the top 30\% BTM ratio of stocks. The medium BTM ratios portfolios were those that were found in $40 \%$ section of the BTM ratios of the stocks, and the bottom 30\% BTM ratios of stocks were for the low BTM portfolios. The paper looked at 120 months, which is from January 2002 to December 2011, which is a ten year period. The paper uses the six portfolios due to the small population of listed companies on the GSE. Its worthy of note that the GSE is a very young market compared to the US stock market which was used in the study by Fama and French (1993). Table 1 presents the formation of the size-BTM portfolios.

Table 1. The formation of the size-BTM portfolios

\begin{tabular}{llccc}
\hline & & & BTM & \\
\cline { 3 - 5 } & & H & M & L \\
\hline \multirow{2}{*}{ SIZE } & S & SH & SM & SL \\
& B & BH & BM & BL \\
\hline
\end{tabular}




\subsection{Estimation of Model Parameters}

\subsubsection{Portfolio Returns (Dependent Variable)}

The dependent variable for both models; the CAPM and the Fama and French Three Factor Models was the excess returns on the six size-BTM portfolios formed. The portfolios returns were computed as equal weighted returns of the stocks in each of the six portfolios. The computing of the returns were done for all the six portfolios. This produced a monthly returns over the period from 2002 to 2011 for each of the six (6) Size-BTM portfolios. The study considered 120 monthly returns during this period. The monthly returns $\left(R_{i, t}\right)$ was derived by using the formula:

Where;

$$
R_{i, t}=\frac{P i, t-P i, t-1}{P i, t-1}
$$

$R_{i, t}=$ monthly returns of stock $i$ at end of month $t$

$P_{i},=$ closing stock price at the end of month $t$

$P_{i},-1=$ closing stock price at the end of previous month $t-1$

The portfolio returns is derived by finding the equal weighted average of all the monthly returns of the individual stocks in the portfolio. It's derived by the formula below as:

$$
P R i, t=\frac{\sum_{i=1}^{n} R_{i, j}}{n_{p}}
$$

Where;

$\mathrm{PR}_{\mathrm{i}, \mathrm{t}}=$ monthly returns of portfolio at end of month $\mathrm{t}$

$\mathrm{R}_{\mathrm{i}, \mathrm{t}}=$ =monthly returns of stock $\mathrm{i}$ in the portfolio at end of month $\mathrm{t}$

$\mathrm{n}_{\mathrm{p}}=$ number of stocks in the portfolio at end of month $\mathrm{t}$

3.4.2 Market Excess Returns (Independent Variable)

This factor is included in both models. The monthly market return was calculated by computing market weighted average returns of all the stocks in the six portfolios for each month including firms which were exclude from portfolio sorting due to them having negative BTM, hence the returns of all the non-financial firms both listed and delisted during the study period. The formula for the monthly market returns is as follows:

$$
\boldsymbol{R}_{m t}=\frac{\sum_{i=1}^{n}\left[\left(X_{i}, P_{i}\right) \boldsymbol{R}_{i, t}\right]}{\sum_{i=1}^{n}\left(X_{i}, P_{i}\right)}
$$

Where;

$R_{m, t}=$ monthly market return for the month $t$.

$X i=$ the outstanding number of shares of stock ' $i$ ' at the end of each year or period

$P i=$ the price of stock ' $i$ ' at the end of the year or period

$R_{i}=$ monthly returns of all stocks $i$ of non-financial firms during study period both listed and de-listed

The market premium or excess returns were calculated from the market monthly return minus risk-free rate. Due to the unavailability of 1-month Treasury bill rate in Ghana, the 91-days Treasury bill rate was used as a proxy for the risk free rate.

\subsubsection{Firm Size (Independent Variable)}

The firm size factor (SMB), which is the difference between the monthly simple average returns of small-size stock portfolios (SH, SM, and SL) and that of monthly average returns of big-size stock portfolios (BH, BM, and $\mathrm{BL})$. The formula is derived as follows:

$$
S M B=\frac{(S H+S M+S L)}{3}-\frac{(B H+B M+B L)}{3}
$$

\subsubsection{Book-to-Market Ratio (BTM) (Independent Variable)}

The third independent variable is the BTM ratio factor (HML), which is the difference between the portfolios simple average returns on the two high-BTM ratio portfolios ( $\mathrm{SH}$ and $\mathrm{BH}$ ) and the portfolios simple average returns on the two low BTM ratio stock portfolios (SL and BL). The formular is as below: 


$$
H M L=\frac{(S H+B H)}{2}-\frac{(S L+B L)}{2}
$$

These are the independent variables which were used for the Fama and French Model, excess market returns, firm size (SMB), and BTM ratio (HML).

\subsection{Data Evaluation and Model Selection}

Since time series data, was employed it seemed prudent to run diagnostic test on the data before running any regression on the data. This is normally done to ensure that certain underlying assumptions are met. To do so, a test on the data must be done by testing of the residuals for the presence of serial correlation and heteroskedasticity as well as testing for the unit root to determine the stationarity of the data. However if these test were done, and the test found the data to be either heteroskedastic or non-stationary. It required the data to be transformed. However many researchers argue that these data transformation processes may lead to the introduction of biases in the estimation of the coefficients. To deal with this problem of heteroskedasticity and non-stationarity of the data, therefore, the regression is run by a robust regression methods, which according to Stock and Watson (2011) takes care of these data challenges.

\section{Presentation of Results and Analysis}

Presented and discussed below are the empirical results from the model.

4.1 Descriptive Statistics for 6 Stock Portfolios Formed on Size and Book-to-Market Equity

Table 2. Descriptive statistics for 6 stock portfolios formed on size and book-to-market equity: 2002-2011

\begin{tabular}{|c|c|c|c|c|c|c|c|}
\hline stats & $\mathbf{N}$ & Mean $(\%)$ & SD & p50 (\%) & $\operatorname{Min}(\%)$ & $\operatorname{Max}(\%)$ & t-test \\
\hline rmrf & 120 & -16.1453 & 7.695552 & -15.6854 & -32.6274 & 18.80445 & $-22.9825 * * *$ \\
\hline smb & 120 & -0.5237 & 4.651688 & -0.42329 & -16.5066 & 14.44306 & -1.2333 \\
\hline hml & 120 & 1.385675 & 4.930849 & 0.894047 & -11.632 & 16.04679 & $3.0784 * * *$ \\
\hline sh & 120 & 2.061753 & 6.040249 & 0.292499 & -11.4003 & 29.698 & $3.7391 * * *$ \\
\hline sm & 120 & 1.068945 & 6.605335 & 0 & -25 & 33.33333 & $1.7728 * *$ \\
\hline sl & 120 & -0.15974 & 4.313697 & 0 & -23.0769 & 28.2441 & -0.4056 \\
\hline bh & 120 & 1.768252 & 6.668835 & 0.101747 & -21.5884 & 33.9779 & $2.9046^{* * *}$ \\
\hline bm & 120 & 1.555405 & 5.673051 & 0.225474 & -12.0077 & 26.92308 & $3.0034 * * *$ \\
\hline bl & 120 & 1.218391 & 6.041194 & 0.292385 & -12.5114 & 28.24357 & $2.2093 * *$ \\
\hline shrf & 120 & -15.4386 & 8.484436 & -14.3952 & -39.2464 & 6.422535 & $-19.9331 * * *$ \\
\hline smrf & 120 & -16.4314 & 9.078554 & -14.0329 & -37.15 & 23.96333 & $-19.8266^{* * *}$ \\
\hline slrf & 120 & -17.6601 & 8.019182 & -17.0206 & -38.3741 & 11.3441 & $-24.1242 * * * *$ \\
\hline bhrf & 120 & -15.7321 & 9.522464 & -14.7025 & -47.6884 & 21.4779 & $-18.0979^{* * *}$ \\
\hline bmrf & 120 & -15.9449 & 8.270515 & -14.3971 & -31.4174 & 10.62308 & $-21.1194 * * *$ \\
\hline blrf & 120 & -16.2819 & 9.105905 & -17.1 & -34.3547 & 10.44357 & $-19.5873 * * * *$ \\
\hline
\end{tabular}

Note. $\mathrm{p}<0.1 * \mathrm{p}<0.05 * * \mathrm{p}<0.001 * * *$.

legend (sh-return on small size but high BTM portfolio, sm-return on small size but medium BTM portfolio, sl-return on small size but low BTM portfolio; bh-return on big size but high BTM portfolio, bm-return on big size but medium BTM, bl-return on big size but low BTM portfolio, shrf, smrf, slrf, bhrf, bmrf, blrf, their respective excess returns, thus shrf is sh minus risk-free; rmrf-market return minus risk-free.

Source: (Authors own construct, survey data, 2015).

The results from Table 2 above shows that, the monthly average mean returns for small firm population is $0.9903 \%$ and for big firms is $1.5140 \%$, the $t$-statistic for the standard deviations for the means of the six size-BTM portfolios shows significant differences between the standard deviations, although only portfolio SL showed no significance at neither $10 \%, 5 \%$, nor $0.1 \%$ significance levels. The average standard deviations for the small firms is 5.6530 and the big firms is 6.1277 . This implies that the big firm portfolios returns are more volatile than the small firm portfolios, as a result the big firm portfolios have a higher risk than the small firm portfolios, and also the large firm portfolios more profitable than the small firm portfolios. For the BTM, the high BTM portfolios mean returns is $1.9150 \%$ and the low BTM portfolios is $0.5293 \%$, this means that high BTM portfolios mean returns are higher than low BTM portfolios. The average standard deviations for the high BTM portfolios is 6.3545 and that of low BTM is 5.1774. This implies that the high BTM portfolios are more risky than the low BTM portfolios. 
The size factor, SMB, is negative and the mean is $-0.5237 \%$ but is not significant at neither $10 \%, 5 \%$, nor $0.1 \%$ significance levels. This implies the size effect is weak considering the Ghana Stock market. The average return of $-0.5237 \%$ per month is different from that recorded by Fama and French (1993) which was $0.27 \%$.

The BTM factor, HML, is positive and the mean is $1.3857 \%$ per month and it is significant at $0.1 \%$ significance level. This implies that there is a strong BTM effect on the returns on the Ghana Stock Exchange. The findings of Fama and French (1993) however was 0.4\% per month.

\subsection{Correlation Matrix among the Independent Variable and Dependent Variable}

The level of interaction amongst the independent and dependent variables, is revealed by the correlation matrix. This provides the ability to check the extent of multicollinearity among the variables. Table 3 presents the correlation matrix of the independent and dependent variables.

Table 3. Correlation matrix of independent and dependent variables

\begin{tabular}{|c|c|c|c|c|c|c|c|c|c|}
\hline & smb & hml & rmrf & shrf & smrf & slrf & bhrf & bmrf & blrf \\
\hline smb & 1 & & & & & & & & \\
\hline hml & $.089 *$ & 1 & & & & & & & \\
\hline rmrf & $-.180^{* *}$ & $-.062 *$ & 1 & & & & & & \\
\hline shrf & $.161^{*}$ & $.245 * * *$ & $.610 * * *$ & 1 & & & & & \\
\hline smrf & $.308^{* * * *}$ & $.088^{*}$ & $.580^{* * *}$ & $.531 * * *$ & 1 & & & & \\
\hline slrf & $.070^{*}$ & $-.266^{* * *}$ & $.698 * * *$ & $.636^{* * *}$ & $.594 * * *$ & 1 & & & \\
\hline bhrf & $-.379^{* * * *}$ & $.297 * * *$ & $.654 * * *$ & $.515^{* * *}$ & $.542 * * *$ & $.648 * * *$ & 1 & & \\
\hline bmrf & $-.234^{* *}$ & $-.063 *$ & $.714^{* * * *}$ & $.652 * * *$ & $.586^{* * *}$ & $.663 * * *$ & $.543^{* * *}$ & 1 & \\
\hline blrf & $-.404^{* * *}$ & $-.309^{* * *}$ & $.705^{* * *}$ & $.645^{* * *}$ & $.444 * * *$ & $.678^{* * *}$ & $.633^{* * *}$ & $.658^{* * * *}$ & 1 \\
\hline
\end{tabular}

From the Table 3, it can be inferred that there is no multicollinearity among the independent variables namely, firm size (SMB), BTM factor (HML), and excess market return (rmrf). The results indicate that the correlation coefficients amongst them is less than 0.5. A negative correlation is recorded between smb and rmrf and is significant at 5\% significance level. This suggests an inverse relationship between size and excess market return. The correlation of $\mathrm{hml}$ and $\mathrm{rmrf}$ is negative and significant at 10\% significance level. Furthermore, there exist a positive correlation between $\mathrm{hml}$ and smb which is significant at $10 \%$ significance level. Also, there exist a strong positive correlation between rmrf and all six dependent variables (shrf, smrf, slrf, bhrf, bmrf, blrf) and are all significant at $1 \%$ significance level. This demonstrations the relationship between excess portfolio returns and market beta. The results from Table 3 also shows a weak correlation of smb and excess portfolio returns which are statistically significant. However, the correlation of smb and small firm portfolio excess' are positive but negative to big firm portfolio return excesses. This means that the smaller size portfolios have a positive effect to firm size, whilst bigger size portfolios have a negative effect to firm size. Table 3 also reveals a positive correlation between $\mathrm{hml}$ and high BTM portfolios excess returns (shrf and bhrf), whilst a negative correlation between hml and low BTM portfolio excess return (slrf and blrf) all being statistically significant. There exist also a positive correlation among all the dependent variables and are statistically significant.

\subsection{Regression Analysis of CAPM}

Table 4. Regression results on CAPM: $R_{a}-R_{f}=\alpha+\beta\left(R m-R_{f}\right)+\varepsilon$

\begin{tabular}{|c|c|c|c|c|c|}
\hline Variable & $\alpha$ & $\beta$ & $\mathrm{N}$ & R-SQUARED & ADJ. R SQUARED \\
\hline \multicolumn{6}{|l|}{ CAPM } \\
\hline SHRF & $-4.5806246^{* *}$ & $.67251461 * * *$ & 120 & 0.372081 & 0.366759 \\
\hline SMRF & $-5.3747953 * * *$ & $.68481773 * * *$ & 120 & 0.336974 & 0.331355 \\
\hline SLRF & $-5.9236216^{* * *}$ & $.72692619 * * *$ & 120 & 0.486631 & 0.482281 \\
\hline BHRF & -2.6670214 & $.80921714 * * *$ & 120 & 0.427672 & 0.422822 \\
\hline BMRF & $-3.5514375^{* *}$ & $.76762182 * * *$ & 120 & 0.510163 & 0.506012 \\
\hline BLRF & $-2.8207764^{*}$ & $.83375094 * * *$ & 120 & 0.496485 & 0.492218 \\
\hline
\end{tabular}

Note. ${ }^{* *} \mathrm{p}<0.05 ; * * * \mathrm{p}<0.01 ; * * * * \mathrm{p}<0.001$.

Source: Survey data, 2015. 
Table 4 presents the regression results for the CAPM. The coefficient of the six size-BTM portfolios excess market return are all positive and statistically significant at $0.1 \%$ significance level. The average beta for all the six size-BTM portfolios is 0.7491 . This shows that the market factor has a significant positive relationship with the excess portfolio returns of the six size-BTM portfolios. The coefficients of the big firm portfolios are higher than those of the small firm portfolios; the difference of 0.1088 is between the average coefficient of big firm portfolios and the average coefficient of small firm portfolios. For the BTM, low BTM portfolios average slope for market factor is 0.7803 and that of high BTM portfolios is 0.7409 , showing a difference of 0.0394 , therefore the average slope of the low BTM portfolios is higher than high BTM portfolios. All these findings support the effect of firm size and BTM effects on the Ghana Stock Exchange.

The intercept of all the six size-BTM portfolios are negative with the intercept of SM and SL portfolios being statistically significant at $0.1 \%$ significance level, the SH and BM portfolios being statistically significant at $1 \%$ significance level, the BL portfolio statistically significant at $5 \%$ significance level, the BH portfolio statistically insignificant. From the six portfolios five of them had intercept which were statistically significant. Merton (1973) stated that the standard asset pricing models intercept should not be statistically different from zero, and the independent variable could fully explain the dependent variable. The implication from this is that, even though the betas for all six portfolios were significant it cannot explain fully the returns as most of its intercepts are statistically significant, signifying that there are other factors which can explain the returns which is not captured by the market beta. The adjusted $\mathrm{R}^{2}$ value of the CAPM is 0.433575 and suggest a low explanatory power. Therefore, Table 4 suggest that CAPM is not sufficient to explain the stock returns on the Ghana Stock Exchange. This finding corroborates Acheampong and Agalega (2013) who observed a similar situation with the CAPM.

\subsection{Regression Analysis of Fama and French Three Factor Model}

Table 5. Regression results of the Fama and French three factor model

\begin{tabular}{lccccccc}
\hline Variable & $\alpha$ & $\beta$ & $S_{i}$ & $h_{i}$ & $\mathrm{~N}$ & $\mathrm{R}-$ SQUARED & ADJ. R SQUARED \\
\hline SHRF & -3.8448657 & $.74171808^{* * * *}$ & $.47159831 * *$ & $.45358857 * * *$ & 120 & 0.516624 & 0.504123 \\
SMRF & -3.6349811 & $.78047376 * * *$ & $.81832382 * * *$ & 0.16824579 & 120 & 0.521382 & 0.509004 \\
SLRF & -4.7587908 & $.7529803^{* * *}$ & $.38201139^{* *}$ & $-.3926763 * *$ & 120 & 0.583878 & 0.573116 \\
BHRF & -4.5871895 & $.77023008^{* * *}$ & $-.61242911^{* * *}$ & $.70000831 * * *$ & 120 & 0.628253 & 0.618638 \\
BMRF & -3.9781833 & $.74597421^{* * *}$ & -0.19279519 & -0.01712335 & 120 & 0.521817 & 0.50945 \\
BLRF & -3.6732645 & $.75896786 * * *$ & $-.52284217 * * *$ & $-.45372686 * * *$ & 120 & 0.635882 & 0.626465 \\
\hline
\end{tabular}

Note. $* \mathrm{p}<0.05 ; * * \mathrm{p}<0.01 ; * * * \mathrm{p}<0.001$

Source: (Authors own construct, Survey data, 2015).

Table 5 above presents the regression results of the excess portfolios return for the six size-BTM portfolios on market factor, size factor (SMB), and BTM factor (HML).

The market factor slopes in Table 4.4 are all positive and statistically significant at $0.1 \%$ significance level. The average slope for the market is 0.758391 and this suggest that market factor is related to portfolio excess return, which assumes an important role in explaining portfolio excess returns. The six Size-BTM portfolios' coefficients are highly significant for 5 out of 6 portfolios. SM, BH, and BL portfolios are significant at $0.1 \%$ significance level, SH and SL are significant 5\% significance level, however BM is insignificant neither at 5\%, $1 \%$, nor $0.1 \%$. The slopes of all the small firm portfolios are positive whiles all the big firm portfolios' coefficients are negative. This findings corroborate Fama and French (1993) who pointed to the fact that small firm portfolios' returns were higher than those of big firm portfolios. The slopes of the BTM factor are all significant except $\mathrm{SM}$ and $\mathrm{BM}$. The portfolio $\mathrm{SH}, \mathrm{BH}$, and $\mathrm{BL}$ are significant at $0.1 \%$ significance level and portfolio SL is significant at $1 \%$ significance level. The portfolios SM and BM are insignificant neither at 5\%, $1 \%$, nor $0.1 \%$ significance level. It can be observed that the slopes of the high BTM portfolios are higher than low BTM portfolios. Within each of the two size portfolios the slopes of BTM factor increased from low BTM portfolios to high BTM portfolios. All this provides evidence of the BTM effect on the Ghana stock Market. The results from this paper corroborate with earlier researchers, including, Fama and French (1993) who posit that firm size and Book-to-Market ratio help in predicting portfolio excess returns.

The average adjusted $\mathrm{R}^{2}$ value of the six size-BTM portfolios is 0.556799 . The BL portfolio gave the highest $\mathrm{R}^{2}$ value of 0.626465 , whilst the lowest $\mathrm{R}^{2}$ value is $\mathrm{SH}$ portfolio. This implies returns of big firms with low BTM 
are better explained by the FFTFM compared to small firms with high BTM. The results from the regression demonstrated that the Fama and French Model can be used on the Ghana's Stock Market to predict the returns of stocks listed. This is seen in the fact that, the additional factors of firm size (SMB) and BTM (HML) which are added to the market factor (beta) provided the Model enough explanatory factors to describe the returns. This is buttressed by the fact that the intercept of all size portfolios were statistically insignificant. Furthermore the regression coefficients of firm size and BTM provides evidence that there exist in the Ghana Stock Market the effects of size and BTM. The betas for all the six size-BTM were positive and significant and goes to show that beta cannot be underestimated when dealing with selecting explanatory factors for returns on the Ghana Market. This is however opposite to the findings of Fama and French (1992), who stipulated that beta is flat in explaining returns. This research showed also that small firm portfolios tend to have higher returns than large firm portfolios, this was evident in the fact that the small firm portfolios had positive slopes and big firm portfolios had negative slopes. This results were consistent with the Fama and French (1993). This paper has also shown that high BTM portfolios tend to have higher returns than low BTM portfolios, this is revealed by the positive slopes for high BTM portfolios and the negative Slopes for Low BTM portfolios. The major inference from the regression was the fact that the $\mathrm{R}^{2}$ value of the Fama and French was higher. This made the Fama and French Model a better model in predicting asset returns on the Ghana Stock Market.

\subsection{Comparison of Fama and French Three Factor Model and CAPM}

Table 6. Comparison of regression results of CAPM with Fama and French three factor model

\begin{tabular}{|c|c|c|c|c|c|c|c|}
\hline Variable & $\alpha$ & $\beta$ & $S i$ & $h i$ & $\mathrm{~N}$ & R-SQUARED & ADJ. R SQUARED \\
\hline \multicolumn{8}{|l|}{ CAPM } \\
\hline SHRF & $-4.5806246^{* *}$ & $.67251461 * * *$ & & & 120 & 0.372081 & 0.366759 \\
\hline SMRF & $-5.3747953 * * *$ & $.68481773 * * *$ & & & 120 & 0.336974 & 0.331355 \\
\hline SLRF & $-5.9236216^{* * * *}$ & $.72692619 * * *$ & & & 120 & 0.486631 & 0.482281 \\
\hline BHRF & -2.6670214 & $.80921714 * * *$ & & & 120 & 0.427672 & 0.422822 \\
\hline BMRF & $-3.5514375^{* *}$ & $.76762182 * * *$ & & & 120 & 0.510163 & 0.506012 \\
\hline BLRF & $-2.8207764^{*}$ & $.83375094 * * *$ & & & 120 & 0.496485 & 0.492218 \\
\hline \multicolumn{8}{|c|}{ Fama French } \\
\hline SHRF & -3.8448657 & $.74171808 * * *$ & $.47159831 * *$ & .45358857 **** & 120 & 0.516624 & 0.504123 \\
\hline SMRF & -3.6349811 & $.78047376^{* * *}$ & $.81832382 * * *$ & 0.16824579 & 120 & 0.521382 & 0.509004 \\
\hline SLRF & -4.7587908 & $.7529803^{* * *}$ & $.38201139 * *$ & $-.3926763 * *$ & 120 & 0.583878 & 0.573116 \\
\hline BHRF & -4.5871895 & $.77023008 * * *$ & $-.61242911 * * *$ & $.70000831^{* * * *}$ & 120 & 0.628253 & 0.618638 \\
\hline BMRF & -3.9781833 & $.74597421 * * *$ & -0.19279519 & -0.01712335 & 120 & 0.521817 & 0.50945 \\
\hline BLRF & -3.6732645 & $.75896786 * * *$ & $-.52284217 * * *$ & $-.45372686^{* * * *}$ & 120 & 0.635882 & 0.626465 \\
\hline
\end{tabular}

Note. $\mathrm{p}<0.05 ; * * \mathrm{p}<0.01 ; * * * \mathrm{p}<0.001$.

Source: Survey data, 2015.

Table 6 draws a comparison of the results of the two asset pricing models tested in this paper. Significant statistical evidence from the results has shown that firm size and BTM factor are relevant in determining the variation in portfolio excess returns on the Ghanaian Stock market. To determine which of the two asset pricing models best explain portfolio returns on the Ghana Stock market, two regressions were run. Firstly a regression with only the excess market returns factor as the explanatory variable to explain the portfolio excess returns is done. This regression is the CAPM regression which shows that the average adjusted $\mathrm{R}^{2}$ value of all the six size-BTM is 0.433575 , however the intercept of the CAPM regression is statistically significant for all the six size-BTM portfolios, and as such it shows that there are other factors that can be added to market excess factor to better explain returns of excess portfolio returns.

The second regression has excess market returns factor, size factor (SMB), and BTM factor (HML) as the explanatory variables to explain the portfolio excess returns. This regression is the Fama and French Three Factor Model (FFTFM), and shows that the average adjusted $\mathrm{R}^{2}$ value is 0.556799 , and the intercept of the FFTFM regression is statistically insignificant at neither $5 \%, 1 \%$, nor $0.1 \%$. What this means is that the FFTFM independent variables of market excess factor, firm size (SMB), and BTM factor (HML) is enough to explain variations in excess portfolio returns. The $\mathrm{R}^{2}$ value of FFTFM is higher than the CAPM. The addition of firm size (SMB) and BTM (HML) to the CAPM independent variable of excess market factor, increases the average adjusted $\mathrm{R}^{2}$ value of the CAPM by $28 \%$. Table 6 present a summary of results of the CAPM and the FFTFM. 
The results from this study confirms the Fama and French (1993) findings, that the firm size (SMB) and BTM factor(HML) are important variables to explain excess portfolio returns, and its explanatory power compared to the CAPM is higher and a better asset pricing model. Comparing the individual adjusted $\mathrm{R}^{2}$ values of the six size-BTM portfolios of the two asset pricing models of CAPM and FFTFM, it is seen that all the $\mathrm{R}^{2}$ values of the six size-BTM portfolios of the FFTFM are higher than that of the CAPM.

\section{Discussion, Conclusion and Policy Implications}

This paper affirms the fact that beta cannot be the only determinants of variations in asset returns. The study has proven that using a multifactor model like the Fama and French Three Factor Model, is a better asset pricing model in explaining the returns of stocks on the Ghana Stock Market than the CAPM. The study further proves the influence of the size effect, initially proposed by Banz (1981), as one of the factors that affects returns on the Ghana Stock Market. The BTM effect is also prominent on stocks on the Ghana Stock Market and is to be considered when predicting future returns.

What can be realized from this paper is that portfolio managers working with stocks listed on the Ghana Stock Exchange must decide how much of each of the three risk factors they are willing to cushion when they are forming their portfolios. They must manage the risk-benefit trade-offs between the three factors to suit their threshold for the various risk factors. This means that, portfolio manager should be able to manage their risk exposures by identifying the true sources of risk. Doing so can maximise their returns at a lower cost. What is also clear from this paper is that the increased expected returns do not depend on any extraordinary performance by an active portfolio manager as shown by the statistically insignificant nature of the alpha values or regression intercepts of the Fama and French Three factor model. This means that, portfolio managers who want to earn higher returns can do so by knowing which stocks will best increase their returns based on the three factors of the Fama-French Model. Furthermore due to the effectiveness of the Fama-French Model in explaining excess portfolio returns it is prudent to recommend that financial analysts as well as academicians devotes more attention to the practicability of this Model and be used more in the world of business to evaluate asset returns.

\section{References}

Acheampong, P., \& Agalega, E. (2013). Does the Capital Assets Pricing Model (CAPM) Predict Stock Market Returns in Ghana? Evidence from Selected Stocks on the Ghana Stock Exchange. Research Journal of Finance and Accounting, 4(9).

Akgun, A., \& Gibson, R. (2001). Recovery Risk in Stocks Returns. The Journal of Portfolio Management, 27(2), 22-31. http://dx.doi.org/10.3905/jpm.2001.319789

Banz, R. W. (1981). The Relationship between Return and Market Value of Common Stocks. Journal of Financial Economics, 9(1), 3-18. http://dx.doi.org/10.1016/0304-405X(81)90018-0

Berk, J. B. (2000). Sorting Out Sorts. Journal of Finance, 55(1), 407-427. http://dx.doi.org/10.1111/0022-1082.00210

Black, F. (1972). Capital Market Equilibrium with Restricted Borrowing. Journal of Business, 45(3), 444-455. http://dx.doi.org/10.1086/295472

Black, F. (1993). Beta and Return. The Journal of Portfolio Management, 20(1), 8-18. http://dx.doi.org/10.3905/jpm.1993.409462

Black, F., Jensen, M. C., \& Scholes, M. S. (1972). The Capital Asset Pricing Model: Some empirical test. In Michael C. Jensen (Ed.), Studies in The Theory of Capital Market. New York: Praeger.

Blume, M. E. (1970). Portfolio Theory: A Step towards its Practical Application. The Journal of Business, 43(2), 152-173. http://dx.doi.org/10.1086/295262

Bodie, Z., Kane, A., \& Marcus, A. J. (2010). Essentials of Investment (8th ed.). New York: McGraw-Hill/Irwin.

Drew, M. E., Naughton, T., \& Veeraraghavan, M. (2003). Firm Size, Book-to-Market Equity and Security Returns: Evidence from the Shanghai Stock Exchange. Australian Journal of Management, 28(2), 119-139. http://dx.doi.org/10.1177/031289620302800201

Fama, E. F., \& French, K. R. (1992). The Cross-section of Expected Stock Returns. The Journal of Finance, 47(2), 427-465. http://dx.doi.org/10.1111/j.1540-6261.1992.tb04398.x

Fama, E. F., \& French, K. R. (1993). Common Risk Factors in the Return of Stocks and Bonds. Journal of Financial Economics, 33(1), 3-56. http://dx.doi.org/10.1016/0304-405X(93)90023-5

Fama, E. F., \& French, K. R. (1996). Multifactor Explanations of Asset Pricing Anomalies. Journal of Finance, 
51(1), 55-84. http://dx.doi.org/10.1111/j.1540-6261.1996.tb05202.x

Fama, E. F., \& French, K. R. (2004). The Capital Asset Pricing Model: Theory and Evidence. Journal of Economic Perspectives, 18(3), 25-46. http://dx.doi.org/10.1257/0895330042162430

Fama, E. F., \& MacBeth, J. D. (1973). Risk, Return, and Equilibrium: Empirical Tests. The Journal of Political Economy, 81(3), 607-636. http://dx.doi.org/10.1086/260061

Ferguson, M. F., \& Shockley, R. L. (2003). Equilibrium “Anomalies”. Journal of Finance, 58(6), 2549-2580. http://dx.doi.org/10.1046/j.1540-6261.2003.00615.x

Friend, I., \& Blume, M. (1970). Measurement of Portfolio Performance Under Uncertainty. The American Economic Review, 60(4), 561-575.

Griffin, J. M., \& Lemmon, M. L. (2002). Book-to-Market Equity, Distress Risk, and Stock Returns. The Journal of Finance, 47(5), 2317-2336. http://dx.doi.org/10.1111/1540-6261.00497

Jensen, M. C. (1968). The Performance of Mutual Funds in the Period 1945-1964. The Journal of Finance, 23(2), 389-416. http://dx.doi.org/10.1111/j.1540-6261.1968.tb00815.x

Ho, Y. W., Strange, R., \& Piesse, J. (2000). CAPM Anomalies and the Pricing of Equity: Evidence from the Hong Kong Market. Applied Economics, 32(12), 1629-1636. http://dx.doi.org/10.1080/000368400419014

Kothari, S., \& Shanken, J. (1997). Book-to-Market, Dividend Yield, and Expected Market Returns: A Time-Series Analysis. Journal of Financial Economics, 44(2), 169-203. http://dx.doi.org/10.1016/S0304-405X(97)00002-0

Lintner, J. (1965). The Valuation of Risk Assets and Selection of Risky Investments in Stock Portfolios and Capital Budgets. The Review of Economics and Statistics, 47(1), 13-37. http://dx.doi.org/10.2307/1924119

Pettengill, G. N., Sundaram, S., \& Mathur, I. (1995). The Conditional Relation between Beta and Returns. The Journal of Financial and Quantitative Analysis, 30(1), 101-116. http://dx.doi.org/10.2307/2331255

Pettengill, G. N., Sundaram, S., \& Mathur, I. (2002). Payment for Risk: Constant Beta Vs. Dual-Beta Models. Financial Review, 37(2), 123-135. http://dx.doi.org/10.1111/1540-6288.00008

Ross, S. A. (1976). The Arbitrage Theory of Capital Asset Pricing. Journal of Economic Theory, 13(3), 341-360. http://dx.doi.org/10.1016/0022-0531(76)90046-6

Sharpe, W. F. (1964). Capital Asset Prices: A Theory of Market Equilibrium under Conditions of Risk. The Journal of Finance, 19(3), 425-442.

\section{Copyrights}

Copyright for this article is retained by the author(s), with first publication rights granted to the journal.

This is an open-access article distributed under the terms and conditions of the Creative Commons Attribution license (http://creativecommons.org/licenses/by/3.0/). 